\title{
Evaluation of survival and recurrence patterns in esophageal cancer patients with pathological response to neoadjuvant chemoradiotherapy
}

\author{
Ali Taghizadeh Kermani ${ }^{1}$, Reza Bagheri ${ }^{2}$, Hessam Taheri ${ }^{2}$, Mohsen Aliakbarian ${ }^{1}$, Ehsan Soltani ${ }^{3}$, Mona Joudi ${ }^{4}$ \\ ${ }^{1}$ Surgical Oncology Research Center, Mashhad University of Medical Sciences, Mashhad, Iran \\ ${ }^{2}$ Lung Diseases Research Center, Mashhad University of Medical Sciences, Mashhad, Iran \\ ${ }^{3}$ Department of General Surgery, Acute Care Surgery Research Center, Mashhad University of Medical Sciences, \\ Taleghani University Hospital, Mashhad, Iran \\ ${ }^{4}$ Cancer Research Center, Mashhad University of Medical Sciences, Mashhad, Iran
}

Kardiochir Torakochir Pol 2019; 16 (4): 186-193

\begin{abstract}
Introduction: There have been a limited number of studies conducted to determine the pattern of relapse and survival in patients after neoadjuvant chemoradiotherapy and surgery for esophageal cancer.

Aim: To evaluate the survival and recurrence patterns in esophageal cancer patients with a pathologic response to neoadjuvant chemoradiotherapy.

Material and methods: This retrospective study was performed on 159 esophageal cancer patients receiving neoadjuvant chemoradiotherapy. A checklist of demographic and clinicopathological variables was filled. Then, survival and recurrence patterns in esophageal cancer patients with complete and near complete pathologic responses to neoadjuvant chemoradiotherapy were evaluated.

Results: Among 159 of 1117 patients who met the inclusion criteria, 147 patients had a complete pathological response and 12 had a near complete pathological response. In this study variables included age, type of tumor and tumor distance from the incisors, which showed no significant difference, and among them, only sex and addiction were associated with the results. The overall survival and 1 year and 3 years disease-free survival were $59.1 \pm 2.5 \%, 89.4 \pm 2.7 \%, 62.8$ $\pm 5.7 \%$ respectively.

Conclusions: Almost all patients with complete pathological responses had well-differentiated cells and those with near complete responses had moderately differentiated cells; the most common type of recurrence was observed in the systemic type of disease and the most common sites were the lungs and liver. Women and people with no history of addiction showed better responses to treatment and had higher levels of survival.
\end{abstract}

Key words: esophageal cancer, survival, recurrence pattern, neoadjuvant chemoradiotherapy.

\section{Streszczenie}

Wprowadzenie: Istnieje ograniczona liczba badań nad mechanizmem nawrotów i przeżyciem pacjentów poddanych chemioterapii neoadiuwantowej i leczeniu chirurgicznemu raka przetyku.

Cel: Ocena przeżycia i mechanizmów nawrotów u chorych na raka przełyku z patologiczną odpowiedzią na chemioterapię neoadiuwantową.

Materiat i metody: Retrospektywne badanie przeprowadzono u 159 pacjentów z rakiem przełyku leczonych chemioterapią neoadiuwantową. Opracowano listę kontrolną zmiennych demograficznych i kliniczno-patologicznych. Następnie poddano ocenie przeżycie oraz mechanizmy nawrotów u pacjentów z rakiem przełyku z całkowitą i niemal całkowitą odpowiedzią patologiczną na chemioterapię neoadiuwantową.

Wyniki: Spośród 159 z 1117 pacjentów, którzy spełnili kryteria włączenia, u 147 odnotowano całkowitą, a u 12 niemal całkowitą odpowiedź patologiczną. W przypadku takich analizowanych zmiennych, jak wiek pacjentów, typ guza i jego odległość od siekaczy, nie stwierdzono istotnych różnic. Jedynie płeć pacjenta oraz uzależnienie w wywiadzie wykazywały zależność z uzyskanymi wynikami. Przeżycie całkowite oraz roczne i trzyletnie przeżycie wolne od choroby wyniosły odpowiednio $59,1 \pm 2,5 \%$, $89,4 \pm 2,7 \%$ oraz $62,8 \pm 5,7 \%$.

Wnioski: Stwierdzono, że u prawie wszystkich pacjentów z całkowitą odpowiedzią patologiczną występował wysoki stopień, a u chorych z niemal całkowitą odpowiedzią - umiarkowany stopień zróżnicowania komórek. Najczęstszym rodzajem nawrotu była choroba uogólniona, obejmująca głównie płuca i wątrobę. U kobiet oraz u pacjentów bez uzależnienia w wywiadzie wykazano lepszą odpowiedź na leczenie i dłuższy okres przeżycia.

Słowa kluczowe: rak przełyku, przeżycie, mechanizm nawrotów, chemioradioterapia neoadiuwantowa.

Address for correspondence: Reza Bagheri MD, Lung Diseases Research Center, Mashhad University of Medical Sciences, 9137913316,

Mashhad, Iran, e-mail: Itrc@mums.ac.ir

Received: 10.06.2019, accepted: 4.12.2019. 


\section{Introduction}

Esophageal cancer is one of the most fatal malignancies worldwide. In 2005, about 497,700 new cases of the disease were reported, which will increase about $140 \%$ by 2025 [1]. Esophageal cancer is the eighth most common malignancy worldwide, leading to nearly 400 thousand deaths every year [2]. This cancer is the sixth leading cause of cancer associated death with 406533 deaths in 2008 [3]. Iran is one of the most well-known regions with high incidence of esophageal cancer; the most cases have been reported in northern regions of Iran [4].

More than $90 \%$ of esophageal cancers include squamous cell carcinoma (SCC) and adenocarcinoma and they are associated with major factors such as histology, geographical location, sex and ethnicity. SCC is the most common in north of China, Turkey and Iran as well as southern states of Russia and other Asian and African countries [5]. Surgery is the treatment of choice for esophageal cancer [1]. However, neoadjuvant chemoradiotherapy has been increasingly used in the treatment of esophageal cancer [4]. Recently, a combination of neoadjuvant chemoradiotherapy followed by esophagectomy is the standard treatment for patients with esophageal cancer [5].

The 5-year survival rate with surgical treatment alone is about $10 \%$ to $20 \%$ [6]. Some studies have shown that surgical treatment after neoadjuvant chemoradiotherapy leads to more favorable results in survival rate compared to surgical treatment alone [7] and a better response to chemoradiotherapy leads to higher rates of patient survival. The total pathologic response rate is currently $25-30 \%$ and many efforts are being made to increase it [4]. Some studies have shown that long-term survival in patients with a complete pathologic response is significantly high [7]. Disease recurrence, which occurs in many cases, is one of the main challenges of the treatment after surgery. The recurrence rate of patients after surgery is $36 \%$ to $56 \%$ [1].

Many recurrences in esophageal cancer after neo-adjuvant chemoradiotherapy and surgery occur at distant locations from the surgical site. The patient survival period after recurrence, regardless of the type of pathological response, is short. Few patients with a complete pathological response experienced recurrence, and if there was a distant recurrence, it happened later than in patients with incomplete pathological responses [8].

A few studies have been conducted to determine the recurrence and survival patterns after esophageal cancer treatment with neoadjuvant chemoradiotherapy and surgery [7].

\section{Aim}

Our aim was to determine recurrence and survival patterns in patients with complete and near complete pathologic responses to neoadjuvant chemoradiotherapy in esophageal cancer patients.

\section{Material and methods}

In a retrospective cohort study, patients with esophageal cancer who underwent neoadjuvant chemoradio- therapy were evaluated in Imam Reza Hospital and Omid Hospital, two tertiary-care teaching centers, affiliated with Mashhad University of Medical Sciences in 2012-2013. The sampling method was purposive.

One hundred eighty-one patients with complete or near complete pathological responses were enrolled in the study. Twenty-two patients were excluded due to lack of hospitalization data, and the 159 remaining patients constituted the study population. All information about age and sex variables, tumor distance from the incisors, tumor location, tumor type, and its gradient were entered in the study checklist. The inclusion criteria for this study were patients with esophageal cancer who underwent neoadjuvant chemoradiotherapy and then surgery, had a complete or near complete pathologic response (pathologic complete response: neoadjuvant chemoradiotherapy consists of: 1) chemotherapy $\left(60 \mathrm{mg} / \mathrm{m}^{2}\right.$ Taxol and $100 \mathrm{mg} / \mathrm{m}^{2}$ carboblasty), 2) radiotherapy consists of radiation therapy in 25-28 sessions with 5000 cGy and 5 fractions.

The term of complete response means: no cancer cell seen in tissue samples removed during surgery or biopsy after treatment. The term of near complete response means: small cancer cell seen in muscle layer in tissue sample removed during surgery. Exclusion criteria were having incomplete files, age below 18, and non-standard doses of neoadjuvant chemoradiotherapy. Determination of the sample size was done using the Poisson method so that all eligible individuals in the desired period of time were selected as samples. All data were entered in SPSS (version 16). According to the available records, at least 150 eligible samples were considered sufficient for this study. The description of the data was done using central indicators and dispersion, and tables and statistical charts. Comparison of survival in patients was done by performing survival analysis (overall survival: the length of time from the date of diagnosis of cancer that patients are still alive). At first, the comparison between the groups was done using the chi-square method for quantitative variables and the Mann-Whitney nonparametric test was used for qualitative variables. Then, to determine the overall survival and disease-free survival in the presence of other variables, the Cox proportional risk model was used and the log rank and Kaplan Meier tests were performed for survival analysis. The $p$-value $<0.05$ is significant.

In this study, the information in the patient records was used and no intervention was performed for the patients. However, the study was registered at the University Ethics Committee. Information about each patient was recorded using the code assigned to the patient, and access to information was only available to project implementers to provide the most complete safety and patient information protection.

This study was conducted on May 20, 2012 at the Faculty/Regional Municipal Organizational Ethics Committee of Mashhad University of Medical Sciences entitled "Determination of Survival Rate and Recurrence Pattern in Patients with Esophageal Cancer with Complete Pathological Re- 
Table I. Frequency distribution of disease characteristics and history

\begin{tabular}{|c|c|}
\hline Parameter & Number (\%) \\
\hline History of dysphagia: & $154(96.9)$ \\
\hline \multicolumn{2}{|l|}{ Grade of dysphagia: } \\
\hline Normal (grade 1) & $5(3.1)$ \\
\hline Needs water with foods (grade 2) & $33(20.8)$ \\
\hline Able to swallow solid foods (grade 3 ) & $101(63.5)$ \\
\hline $\begin{array}{l}\text { Able to swallow liquefied foods and liquids only } \\
\text { (grade 4) }\end{array}$ & $19(11.9)$ \\
\hline Unable to swallow saliva (grade 5) & $1(0.6)$ \\
\hline Odynophagia: & $21(13.2)$ \\
\hline \multicolumn{2}{|l|}{ Amount of weight loss in the last 6 months: } \\
\hline More than $10 \%$ & $37(23.3)$ \\
\hline Less than $10 \%$ & $60(37.7)$ \\
\hline No & $62(39)$ \\
\hline \multicolumn{2}{|l|}{ Performance (ECOG): } \\
\hline Normal activity and asymptomatic (grade 0 ) & $11(6.9)$ \\
\hline Active but symptomatic(grade 1 ) & $104(65.4)$ \\
\hline Symptomatic + relatively active (grade 2 ) & $44(27.7)$ \\
\hline \multicolumn{2}{|l|}{ Comorbidities: } \\
\hline Diabetes & $8(5)$ \\
\hline Cardiac disease & $8(5)$ \\
\hline Hypertension & $20(12.6)$ \\
\hline Surgery & $5(3.1)$ \\
\hline Other & $22(13.8)$ \\
\hline Family history: & $13(8.2)$ \\
\hline \multicolumn{2}{|l|}{ Social history: } \\
\hline Smoking & $24(15.1)$ \\
\hline Addiction & $40(25.2)$ \\
\hline
\end{tabular}

sponse to Neoadjuvant Chemoradiotherapy", No. 931327, code 8799P.

\section{Results}

The total number of cases reviewed was 1117, of which 159 met the inclusion criteria; 83 (52.2\%) were men and $76(47.8 \%)$ were women.

The mean age was $58.6 \pm 20.19$ years and most of the studied population (124 people) were Persian (78.0\%). All the women who participated were housewives. Among the men $48.2 \%$ were framers and $25.3 \%$ were laborers. Body mass index was $21.44 \pm 4.40$. Table I shows the frequency distribution of the characteristics and history of the disease in the subjects.

Table II shows the frequency distribution of patients' status at the last visit based on the biological response.

Regarding the recurrence pattern after treatment, local recurrence mostly present in the anastomosis was observed in $6(24 \%)$ patients and in the mediastinum in $2(8 \%)$ patients. In systemic recurrence, the most common recurrence was observed in the lungs with 7 (28\%) patients and then in the liver with 6 (24\%) patients and in the lymph nodes with 4 (16\%) patients.

Table III shows the relationship between disease state according to diagnostic and therapeutic profile and pathologic response.

Patients were followed up between 3 and 86 months; the median follow-up was 12 months. The median overall survival (the length of time from the date of diagnosis of cancer that patients are still alive) was 52 months and the mean total survival was 56.1 months. One-year survival was $89.4 \pm 2.7 \%$, and the 3 -year survival was $62.8 \pm 6.3 \%$. The disease-free median survival period (DFS: the length of time after primary treatment that the patient survives with-

Table II. Frequency distribution of patients' status at the last visit based on the biological response

\begin{tabular}{|c|c|c|c|c|c|}
\hline \multirow[t]{2}{*}{ Parameter } & \multirow{2}{*}{$\begin{array}{l}\text { Total } \\
n(\%)\end{array}$} & \multicolumn{2}{|c|}{ Pathological response } & \multicolumn{2}{|c|}{$\chi^{2}$ results } \\
\hline & & $\begin{array}{c}\text { Complete } \\
n(\%)\end{array}$ & $\begin{array}{c}\text { Near complete } \\
n(\%)\end{array}$ & Statistics & $P$-value \\
\hline Recurrence: & & & & 0.009 & 0.926 \\
\hline Yes & $25(15.7)$ & $23(15.6)$ & $2(16.7)$ & & \\
\hline No & $134(84.3)$ & $124(84.4)$ & $10(83.3)$ & & \\
\hline Type of recurrence: & & & & & 0.999 \\
\hline local & $9(36)$ & $8(34.8)$ & $1(50)$ & & \\
\hline Systemic & $16(64)$ & $15(62.5)$ & $1(50)$ & & \\
\hline The last visited status: & & & & 1.93 & 0.381 \\
\hline Desirable & $120(75.5)$ & $112(76.2)$ & $8(66.7)$ & & \\
\hline Undesirable & $35(22)$ & $32(21.8)$ & $3(25)$ & & \\
\hline Lost & $4(2.5)$ & $3(2)$ & $1(8.3)$ & & \\
\hline Consequences: & & & & 1.24 & 0.264 \\
\hline Dead & $33(20.8)$ & $29(19.7)$ & $4(33.3)$ & & \\
\hline Alive & $126(79.2)$ & $118(80.3)$ & $8(66.7)$ & & \\
\hline Total & & 147 (92.5) & $12(7.5)$ & & \\
\hline
\end{tabular}


Table III. Evaluation of the association between disease status according to diagnostic and therapeutic profile and pathological response

\begin{tabular}{|c|c|c|c|c|c|c|}
\hline \multirow[t]{2}{*}{ Parameter } & & \multirow{2}{*}{$\begin{array}{l}\text { Total } \\
n(\%)\end{array}$} & \multirow{2}{*}{$\begin{array}{l}\text { Complete } \\
n(\%)\end{array}$} & \multirow{2}{*}{$\begin{array}{c}\text { Near complete } \\
n(\%)\end{array}$} & \multicolumn{2}{|c|}{$\chi^{2}$ results } \\
\hline & & & & & Statistics & $P$-value \\
\hline \multicolumn{5}{|c|}{ Endoscopic findings: } & 0.004 & 0.999 \\
\hline \multirow[t]{2}{*}{ Tolerable } & Yes & $145(91.2)$ & $134(91.2)$ & $11(91.7)$ & & \\
\hline & No & $14(8.8)$ & $13(8.8)$ & $1(8.3)$ & & \\
\hline \multirow[t]{3}{*}{ Form of lesion } & Vegetative & $65(41.1)$ & $59(40.4)$ & $6(50)$ & 1.53 & 0.853 \\
\hline & Ulcero-vegetative & $43(27.2)$ & $36(26.7)$ & $4(33.3)$ & & \\
\hline & Mass & $50(31.6)$ & $48(32.9)$ & $2(16.7)$ & & \\
\hline \multicolumn{5}{|c|}{ Location of the lesion: } & 0.411 & 0.836 \\
\hline \multicolumn{2}{|c|}{ Middle esophagus } & $36(22.6)$ & $33(22.4)$ & $3(25)$ & & \\
\hline \multicolumn{2}{|c|}{ Lower esophagus } & $98(61.6)$ & $90(61.2)$ & $8(66.7)$ & & \\
\hline \multicolumn{2}{|c|}{ Middle and lower } & $25(15.7)$ & $24(16.3)$ & $1(8.3)$ & & \\
\hline \multicolumn{2}{|c|}{ Type of tumor: } & & & & & 0.999 \\
\hline \multicolumn{2}{|l|}{$\mathrm{SCC}$} & $150(94.3)$ & 138 (93.9) & $12(100)$ & & \\
\hline \multicolumn{2}{|c|}{ Adenocarcinoma } & $9(5.7)$ & $9(6.1)$ & $0(0)$ & & \\
\hline \multicolumn{2}{|l|}{ Cell's grade: } & & & & 6.92 & 0.055 \\
\hline \multicolumn{2}{|c|}{ Undifferentiated } & $3(1.9)$ & $2(1.4)$ & $1(8.3)$ & & \\
\hline \multicolumn{2}{|l|}{ Good } & $74(46.5)$ & $71(48.3)$ & $3(25)$ & & \\
\hline \multicolumn{2}{|l|}{ Average } & $65(40.9)$ & $57(38.8)$ & $8(66.7)$ & & \\
\hline \multicolumn{2}{|l|}{ Weak } & $17(10.7)$ & 17 (11.6) & $0(0)$ & & \\
\hline \multicolumn{2}{|c|}{ Chemotherapy regimen: } & & & & 4.53 & 0.717 \\
\hline \multicolumn{2}{|l|}{ Cisplatin + 5FU } & $119(74.8)$ & $110(74.8)$ & $9(75)$ & & \\
\hline \multicolumn{2}{|c|}{ Cisplatin + irinotecan } & $7(4.4)$ & $6(4.1)$ & $1(8.3)$ & & \\
\hline \multicolumn{2}{|c|}{ Paclitaxel + carboplatin } & $28(17.6)$ & $26(17.7)$ & $2(16.7)$ & & \\
\hline \multicolumn{2}{|l|}{ Other } & $5(3.1)$ & $5(3.1)$ & $0(0)$ & & \\
\hline \multicolumn{2}{|l|}{ Type of surgery: } & & & & & 0.999 \\
\hline Trans-hiatal & & $131(82.4)$ & $121(82.3)$ & $10(83.3)$ & & \\
\hline Trans-thoracic & & $28(17.6)$ & $26(17.7)$ & $2(16.7)$ & & \\
\hline BMI: & & & & & 5.97 & 0.050 \\
\hline Less than norm & $(<18.5)$ & $35(22)$ & $29(19.7)$ & $6(50)$ & & \\
\hline Normal (18.5-2 & & $89(56)$ & $85(57.8)$ & $4(33.3)$ & & \\
\hline More than norn & l $(>25)$ & $35(22)$ & $33(22.4)$ & $2(16.7)$ & & \\
\hline Parameter & & & Mean & & & \\
\hline Age & & $59.5(19)$ & $60(16)$ & $55(18)$ & 0.757 & 0.449 \\
\hline Surface area (SA) & & $1.52(0.23)$ & $1.52(0.23)$ & $1.50(0.28)$ & 0.524 & 0.601 \\
\hline BMI & & $20.9(5.5)$ & $21.2(5.3)$ & $17.3(5.7)$ & 1.11 & 0.265 \\
\hline Distance from in & ors & $30(5.2)$ & $30(5)$ & $28(9)$ & 0.488 & 0.626 \\
\hline Length of the les & & $3(3.5)$ & $3(3.5)$ & $2(2.7)$ & 0.235 & 0.815 \\
\hline Number of chem & herapy sessions & $1(1)$ & $2(1)$ & $1(0)$ & 2.54 & 0.011 \\
\hline
\end{tabular}

out any sign or symptoms of that cancer) was 52 months and the mean was 62.9 months. The 1-year disease-free survival rate was $93.6 \pm 2.2 \%$ and the 3 -year disease-free survival rate was $72.3 \pm 5.4 \%$. Figure 1 shows the total survival function of the follow-up period.

The results of the study of the effect of gender on overall survival and disease-free survival are shown in Tables I-IV. Kaplan-Meier analysis was used to assess the survival of the patients; the mean survival of women was 66.3 months and the average survival of men was 51.5 months; the comparison of survival was evaluated by a rank logarithm test, in which the survival of women was significantly higher than the survival of men during the follow-up period ( $p=0.038$, $p=0.24,28.4)$. The mean disease-free survival of women was 68.1 months and the mean disease-free survival of men was 58.1 months, and there was no significant difference in the 


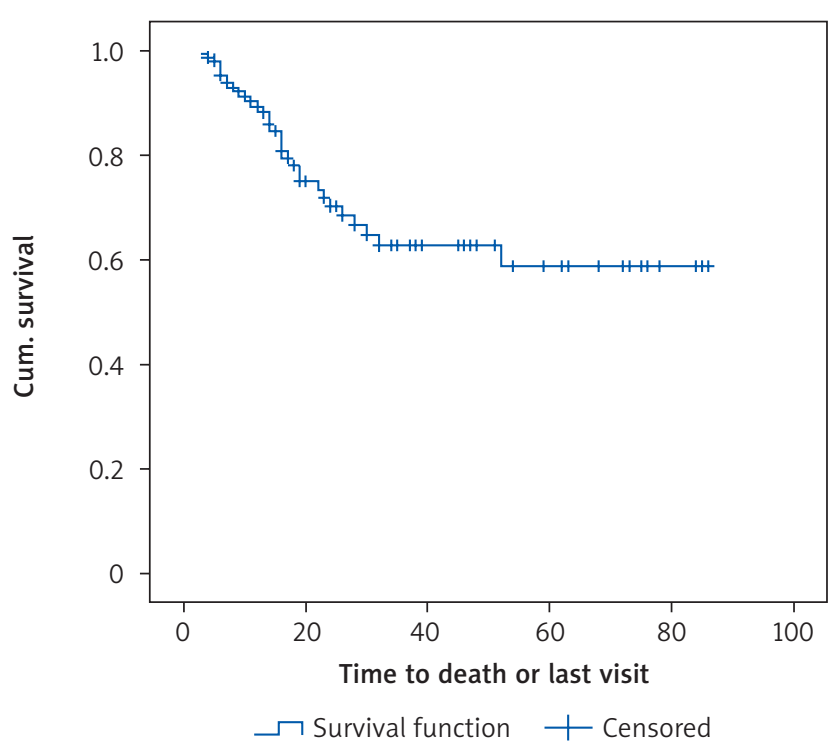

Figure 1. Overall survival functions of patients during follow-up survival rates of women in comparison with men $(p=0.252)$. Figure 2 shows the overall survival function of the sex population.

The age of the patients (more than 60 years and less than 60 years old) did not affect overall survival ( $p=0.612$ ) or disease-free survival $(p=0.725)$. The location of the lesion also had no effect on overall survival $(p=0.736)$ or disease-free survival $(p=0.469)$. Pathological grade also had no effect on overall survival ( $p=0.602$ ) or diseasefree survival $(p=0.920)$. Although the pathologic response did not show significant difference in patient survival $(p=0.15)$, in patients with a complete pathological response, 29 (19.7\%) died, and had a mean survival of 60 months, and in patients with a near complete response, $4(33.3 \%)$ died and the average survival was 35.5 months. Figure 3 shows the overall survival function of the patients in terms of pathological response.

Patients consuming narcotic drugs had a mean survival of 44.4 months and non-consuming patients had a mean

Table IV. Evaluation of the association between disease status according to diagnostic and therapeutic profile and patient survival

\begin{tabular}{|c|c|c|c|c|c|}
\hline \multicolumn{2}{|l|}{ Parameter } & Number (\%) & Mean survival (SD) & $\begin{array}{c}\text { Results } \\
\text { statistics }\end{array}$ & $P$-value \\
\hline \multicolumn{2}{|c|}{ Endoscopic findings (form of the lesion): } & & & 0.618 & 0.892 \\
\hline \multicolumn{2}{|c|}{$\underline{\text { Vegetative }}$} & $15(23.1 \%)$ & $60.6(5.4)$ & & \\
\hline \multicolumn{2}{|c|}{ Ulcero-vegetative } & $8(18.6)$ & $53.9(9.2)$ & & \\
\hline \multicolumn{2}{|l|}{ Mass } & $8(18.6)$ & $55.3(6.6)$ & & \\
\hline \multicolumn{2}{|c|}{ Location of the lesion: } & & & 0.614 & 0.736 \\
\hline \multicolumn{2}{|c|}{ Middle esophagus } & $9(0.25)$ & $56.1(7.3)$ & & \\
\hline \multicolumn{2}{|c|}{ Lower esophagus } & $20(20.4)$ & $58.1(5.1)$ & & \\
\hline \multicolumn{2}{|c|}{ Middle and lower esophagus } & $4(15.6)$ & $67.5(7.9)$ & & \\
\hline \multicolumn{2}{|c|}{ Type of surgery: } & & & 0.029 & 0.865 \\
\hline \multicolumn{2}{|c|}{ Trans-hiatal } & $26(19.8)$ & $59.1(4.4)$ & & \\
\hline \multicolumn{2}{|c|}{ Trans-thoracic } & $7(0.25)$ & $57(8.2)$ & & \\
\hline \multicolumn{2}{|l|}{ BMI: } & & & 0.947 & 0.623 \\
\hline \multicolumn{2}{|c|}{ Less than normal $(<18.5)$} & $9(25.7)$ & $56.2(7.8)$ & & \\
\hline \multicolumn{2}{|c|}{ Normal (18.5-25) } & $20(22.5)$ & $58.3(5)$ & & \\
\hline \multicolumn{2}{|c|}{ More than normal (> 25) } & $4(11.4)$ & $57.1(7.8)$ & & \\
\hline \multicolumn{2}{|c|}{ Grade of dysphagia: } & & & 1.01 & 0.605 \\
\hline \multicolumn{2}{|c|}{ Normal and average (grade 1 and 2) } & $8(21.1)$ & $62.7(7.3)$ & & \\
\hline \multicolumn{2}{|c|}{ Solid foods (grade 3) } & $20(19.8)$ & $58.6(4.7)$ & & \\
\hline \multicolumn{2}{|c|}{ Liquid and saliva (grade 4) } & $5(0.25)$ & $37.3(8)$ & & \\
\hline \multicolumn{2}{|c|}{ Performance ECOG: } & & & 2.48 & 0.115 \\
\hline \multicolumn{2}{|c|}{ Normal activity asymptomatic (grade 0 ) } & $1(9.1)$ & $61.2(6.3)$ & & \\
\hline \multicolumn{2}{|c|}{ Active but symptomatic (grade 1) } & $20(19.2)$ & $62(4.5)$ & & \\
\hline \multicolumn{2}{|c|}{ Symptomatic + relatively active (grade 2 ) } & $12(27.3)$ & $47.1(7.5)$ & & \\
\hline \multicolumn{2}{|c|}{ Social history: } & & & 1.39 & 0.242 \\
\hline \multirow[t]{2}{*}{ Smoking } & Yes & $3(12.5)$ & $67.7(8.6)$ & & \\
\hline & No & $30(23.7)$ & $56.9(4.3)$ & & \\
\hline \multirow[t]{2}{*}{ Addiction } & Yes & $13(33.5)$ & $44.4(7.8)$ & 6.52 & 0.011 \\
\hline & No & 20 (17.2) & 63.5 (3.9) & & \\
\hline
\end{tabular}




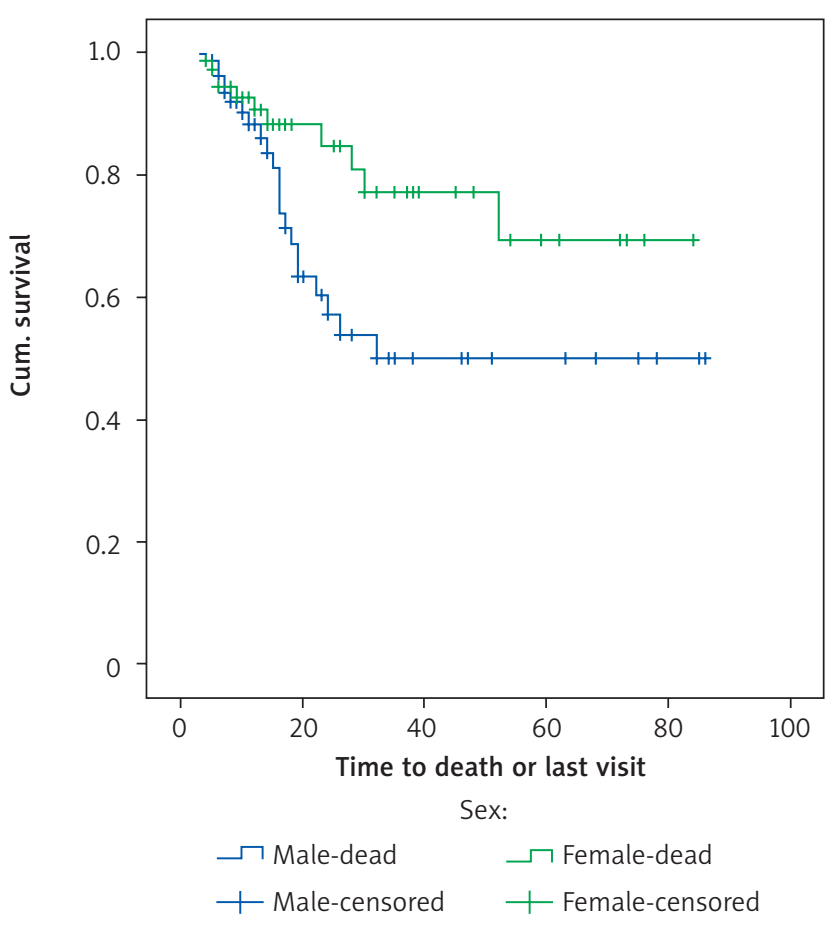

Figure 2. The overall survival function of patients in terms of gender

survival of 63.5 months; the results showed a significant difference in the survival of drug users $(p=0.1111)$. Also, the average survival time of patients with normal and mean normal performance was 1.63 months and in the lower or more active group with symptoms of disease was 47.1 months, but no significant difference was observed. In Table IV, the association between the disease status and the diagnostic-therapeutic profile and survival of patients has been investigated.

\section{Discussion}

Our results demonstrated that the survival of women was significantly higher than that of men during the follow-up period ( $p=0.038, p=0.24,28.4$ ), but there was no significant difference in the survival rates of women in comparison with men $(p=0.252)$. The age of the patients (more than 60 years and less than 60 years old) did not affect overall survival $(p=0.612)$ or disease-free survival $(p=0.725)$. The location of the lesion also had no effect on overall survival $(p=0.736)$ or disease-free survival $(p=0.469)$. Pathological grade also had no effect on overall survival ( $p=0.602)$ or disease-free survival $(p=0.920)$. The pathologic response did not show a significant difference in patient survival ( $p=0.15$ ). A study demonstrated that out of 205 patients who underwent neoadjuvant chemoradiotherapy for esophageal adrenocarcinoma, 38 (19\%) had a complete pathological response and 167 (81\%) had an incomplete pathological response, and with a median follow-up of 50 months; the overall survival, and three years recurrence-free survival for incomplete pathological response were $48 \%$ and $39 \%$ respectively, and for complete pathological response they were $86 \%$ and $80 \%$ respec-

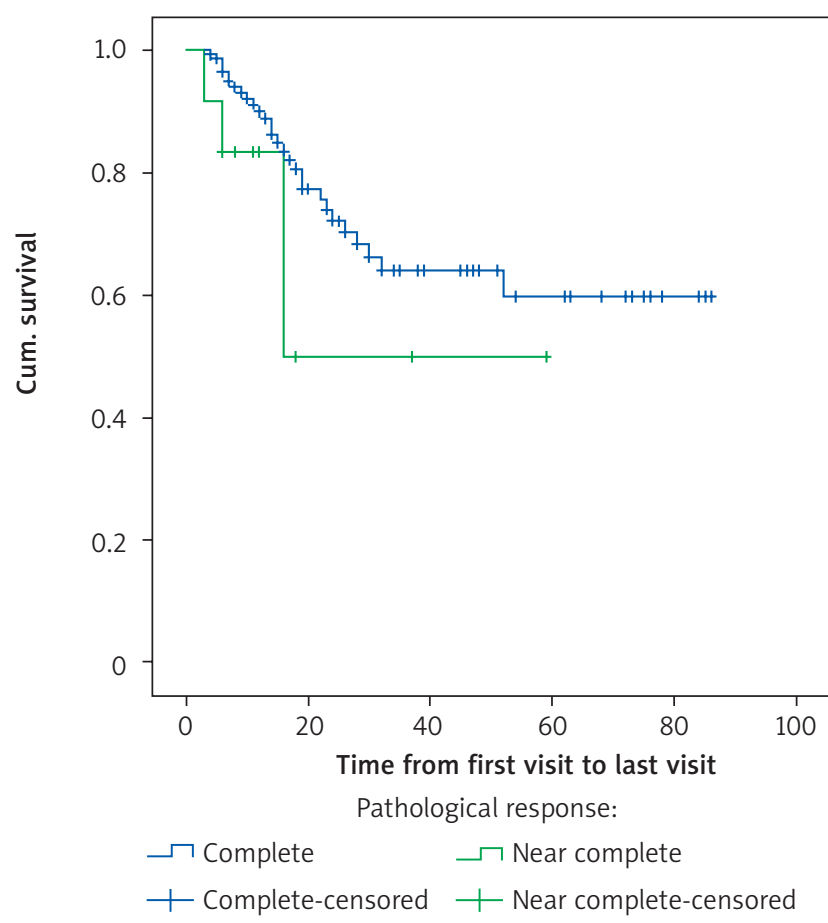

Figure 3. Overall survival function of patients in terms of pathological response

tively, reflecting the benefits of neoadjuvant therapy for esophageal adenocarcinoma, especially when associated with a complete pathological response [9]. A retrospective study on 83 patients with thoracic and cervical recurrence after esophageal cancer surgery concluded that chemoradiotherapy and 3D radiotherapy had a significant effect on the post-operative recurrence of esophageal cancer, and long-term survival occurs in patients who achieve complete pathological recovery after chemoradiotherapy. With a median follow-up of 34 months, the overall 3-year survival rate for all patients was $51.8 \%$. The overall tumor response was $75.9 \%$, which was $44.6 \%$ in patients with a complete response. Forty-seven patients developed advanced disease after chemoradiotherapy; 27 of them (57.4\%) had topical invasions and 18 patients (38.3\%) had distant metastases [1].

A meta-analysis of the effect of neoadjuvant chemotherapy and chemoradiotherapy prior to esophageal cancer surgery, compared to surgery alone concluded that this treatment increased the risk of pre-operative mortality and post-operative complications and there is no significant difference between chemotherapy and neoadjuvant chemoradiotherapy. Neoadjuvant chemoradiotherapy should also be monitored in patients with squamous cell carcinoma, since it seems to increase the risk of mortality, especially after surgery [2].

A study assessing the rate and pattern of post-neoadjuvant chemoradiotherapy recurrence in patients with esophageal cancers found that a neoadjuvant chemoradiotherapy regimen had a positive effect on the result of the treatment and recurrence pattern. These findings are, however, influenced by the complete pathological response and the complete removal of the micrometastases in the 
CRT process; analyzing 204 patients, of whom 75 patients underwent neoadjuvant chemoradiotherapy and 129 patients underwent surgery alone, a pathological response to neoadjuvant chemoradiotherapy was observed in 52 (69\%) patients, of whom 19 (25\%) had complete responses. The 3 - and 5-year survival rates in neo-adjuvant chemoradiotherapy were $53 \%, 42 \%, 24 \%$ and $18 \%$ compared to surgery alone. The disease-free survival and 3- and 5-year overall survival rates in complete response were $79 \%$ for all four, while for non-responders they were $26 \%, 0 \%, 37 \%$ and $28 \%$ respectively [6].

A study reported that although neoadjuvant chemoradiotherapy leads to a better pathological response rate compared to chemotherapy, this does not guarantee longterm survival, and chemotherapy alone may be the preferred route of treatment due to its accelerating effect on removal of the tumor and reducing mortality and morbidity during and after surgery and increasing survival in patients with esophageal cancers. Comorbid therapy was performed on 64 patients and chemotherapy was performed on 58 patients, and the complete pathological response was observed in 11 patients with chemoradiotherapy and 2 patients with chemotherapy, and no difference was observed in the recurrence pattern between the two groups. The 1-, 3-, and 5-year survival rates in chemoradiotherapy were $76 \%, 46 \%, 41 \%$, and in chemotherapy they were $70 \%$, $49 \%$, and $31 \%$ respectively [7].

One study found that esophagogastrectomy after neoadjuvant chemoradiotherapy may lead to lower mortality. Patients with a complete pathological response showed a higher long-term survival rate compared to those with near complete or relatively complete pathologic responses. However, these researchers have suggested further studies to determine the complete pathological response. In this study, 132 of 162 patients underwent esophagogastrectomy and a complete pathological response was obtained in 42 (26\%) patients and a near complete pathological response was obtained in 27 (17\%) patients and a relative complete pathological response was obtained in 88 (54\%) and 5 (3\%) patients were unresectably reported. The overall 5-year survival, the complete pathological response, near complete and relatively complete pathological responses were $34 \%$, $55 \%, 27 \%$, and $27 \%$ respectively [8].

It was reported in a 2014 study that neoadjuvant chemoradiotherapy with three-incision esophagectomy is a safe method and does not increase post-surgical mortality. The surgical outcomes were compared to 92 patients in the two groups who did not receive the first neoadjuvant chemoradiotherapy with 114 patients and the second group who received neoadjuvant chemoradiotherapy. Overall mortality in the first group was $44.7 \%$ and in the second group was $55.4 \%$, and the complications of surgery did not show any difference between the two groups [10]. Meguid et al. stated that most of the recurrences after neoadjuvant therapy are short term. However, recurrence in patients with a complete pathological response is very rare and recurrence occurs later in them, and only the pathological response is clearly related to the recurrence of the disease. Eighty-two of 267 patients (30.7\%) showed a complete pathological response with neoadjuvant therapy, and 108 (40.4\%) patients and 77 (28.8\%) patients had a relative response and no response, respectively. Eighty-four patients had a recurrence, of whom 18 (21.4\%) patients had a complete response, 39 (36.1\%) had a relative response, and 27 (35.1\%) had no response. Sixty-five $(77.4 \%)$ patients had a distance recurrence with a mean survival of 37.8 months, regardless of pathological response, and there was no difference in recurrence location for patients with a relative response and no response, while for patients with a complete response, distance recurrence occurred over a longer period. The median disease-free survival in these patients was 3.27 months. In multivariate analyses, no factor other than pathological response to neoadjuvant therapy was associated with recurrence or death, so that patients with a relative response or no pathological response had 1.97 and 2.32 times more recurrences than patients with a complete pathological response [11].

Some authors conducted a study on the pattern of failure of treatment and recurrence after neo-adjuvant chemoradiotherapy and surgery in patients with esophageal cancers and reported that a small number of patients had trouble in their abdominal para-aortic glands or their lymph nodes in the first recurrence of the disease, and it is unlikely that targeting the lymphatic area with radiotherapy can improve clinical outcomes [12].

Localized control and disease-free survival and 2-year overall survival in 155 patients in whom the primary location of the tumor was $18 \%$ in the upper and middle part of the esophagus, 32\% in the lower esophagus and 50\% in the esophageal and gastric junction (79\% adenocarcinoma and $21 \%$ SCC) were $86 \%, 36 \%$ and $48 \%$ respectively [ 12 ].

The authors of the study concluded that preoperative chemoradiotherapy in patients with esophageal cancers reduced locoregional recurrence and peritoneal carcinomatosis, and recurrence occurred only in $5 \%$ of patient during radiation.

From 422 patients between 2001 and 2008 (of whom 418 were available) and most of them had a histology of adenocarcinoma (75\%), 374 patients underwent resection, with $86 \%$ undergoing surgery and $92 \%$ undergoing chemoradiotherapy and surgery. After a follow-up of at least 24 months, the overall rate of recurrence in surgery was $58 \%$ vs. $35 \%$. Preoperative chemoradiotherapy therapy reduced local recurrence from $34 \%$ to $14 \%$, and peritoneal carcinomatosis from $14 \%$ to $4 \%$ [13].

Some authors in a study conducted a study on 128 patients who randomly underwent surgery alone and 128 others undergoing neoadjuvant chemoradiotherapy with cisplatin and fluorouracil, and then surgery, concluded that neoadjuvant chemoradiotherapy significantly improved overall survival compared to patients undergoing surgery alone, although their subsequent evaluations showed the positive effects of neoadjuvant chemoradiotherapy in squamous cell carcinoma tumors [14]. 
According to Kermani et al., there was no significant relationship between genetic links between HER-2/neu and age, sex, and invasion, tumor location, TNM stage and stage tumor [15]. According to Bagheri et al., micrometastasis in esophageal cancer (bone marrow involvement without macroscopic involvement elsewhere) is geographically dependent and has a direct relationship with tumor grade and lymph node involvement [16].

In this study, we evaluated total survival and diseasefree survival variables in patients with esophageal cancers undergoing neoadjuvant chemoradiotherapy with complete or near complete pathological responses. Other variables such as age, sex, type of tumor, degree of differentiation, the distances from incisors, tolerance or intolerance of endoscope, BMI, and using drugs were also analyzed.

\section{Conclusions}

Our aim was to evaluate the survival and recurrence patterns in esophageal cancer patients with a pathologic response to neoadjuvant chemoradiotherapy.

In our study, the one-year survival rate was $59.1 \pm 2.5$, $89.4 \pm 2.71$ and the 3 -year survival rate was $62.8 \pm 5.7 \%$ reliable competition with other study. However, further studies are needed for more accurate result in decision making. It is noted that overall survival and disease-free survival in patients with a complete pathological response are clearly better than in other groups; the most common recurrences were systemic and occurred in the lungs and the liver, and patient mortality was associated with recurrence of the disease.

\section{Acknowledgments}

This article was conducted with financial support provided by the Lung Diseases Research Center of Mashhad University of Medical Sciences, Mashhad, Iran.

The authors would like to thank the Vice Chancellor of Research Council of Mashhad University of Medical Sciences for their kind support.

\section{Disclosure}

The authors report no conflict of interest.

\section{References}

1. Bao Y, Liu S, Zhou Q, Cai P, Anfossi S, Li Q, Hu Y, Liu M, Fu J, Rong T, Li Q, Liu H. Three-dimensional conformal radiotherapy with concurrent chemotherapy for postoperative recurrence of esophageal squamous cell carcinoma: clinical efficacy and failure pattern. Radiation Oncology 2013; 8: 241.

2. Kumagai K, Rouvelas I, Tsai J, Mariosa D, Klevebro F, Lindblad M, Ye W, Lundell L, Nilsson M. Meta-analysis of postoperative morbidity and perioperative mortality in patients receiving neoadjuvant chemotherapy or chemoradiotherapy for resectable oesophageal and gastro oesophageal junctional cancers. Br J Surg 2014; 101: 321-338.

3. Fujiwara Y, Yoshikawa R, Kamikonya N, Nakayama T, Kitani K, Tsujie M, Yukawa M, Hara J, Yamamura T, Inoue M. Neoadjuvant chemoradiotherapy followed by esophagectomy vs. surgery alone in the treatment of resectable esophageal squamous cell carcinoma. Mol Clin Oncol 2013; 1: 773-779.

4. Ghavamzadeh A, Moussavi A, Jahani M, Rastegarpanah M, Iravani M. Esophageal cancer in Iran. Semin Oncol 2001; 28: 153-157.

5. Halperin EC, Brady LW, Perez CA, Wazer DE. Perez \& Brady's principles and practice of radiation oncology: Lippincott Williams \& Wilkins, 2013.

6. Smit JK, Güler S, Beukema JC, Mul VE, Burgerhof JG, Hospers GA, Plukker JT. Different recurrence pattern after neoadjuvant chemoradiotherapy compared to surgery alone in esophageal cancer patients. Ann Surg Oncol 2013; 20: 4008-4015.

7. Luu TD, Gaur P, Force SD, Staley CA, Mansour KA, Miller JI Jr, Miller DL. Neoadjuvant chemoradiation versus chemotherapy for patients undergoing esophagectomy for esophageal cancer. Ann Thorac Surg 2008; 85: 1217-1223.

8. Donahue JM, Nichols FC, Li Z, Schomas DA, Allen MS, Cassivi SD, Jatoi A, Miller RC, Wigle DA, Shen KR, Deschamps C. Complete pathologic response after neoadjuvant chemoradiotherapy for esophageal cancer is associated with enhanced survival. Ann Thorac Surg 2009; 87: 392-398.

9. Alnaji RM, Du W, Gabriel E, Singla S, Attwood K, Nava H, Malhotra U, Hochwald SN, Kukar M. Pathologic complete response is an independent predictor of improved survival following neoadjuvant chemoradiation for esophageal adenocarcinoma. J Gastrointest Surg 2016; 20: 1541-1546.

10. Hamai Y, Hihara J, Taomoto J, Yamakita I, Ibuki Y, Okada M. Effects of neoadjuvant chemoradiotherapy on postoperative morbidity and mortality associated with esophageal cancer. Dis Esophagus 2015; 28: 358-364.

11. Meguid RA, Hooker CM, Taylor JT, Kleinberg LR, Cattaneo II SM, Sussman MS, Yang SC, Heitmiller RF, Forastiere AA, Brock MV. Recurrence after neoadjuvant chemoradiation and surgery for esophageal cancer: does the pattern of recurrence differ for patients with complete response and those with partial or no response? J Thorac Cardiovasc Surg 2009; 138: 1309-1317.

12. Dorth JA, Pura JA, Palta M, Willett CG, Uronis HE, D'amico TA, Czito BG. Patterns of recurrence after trimodality therapy for esophageal cancer. Cancer 2014; 120: 2099-2105.

13. Oppedijk V, van der Gaast A, van Lanschot JJ, van Hagen P, van Os R, van Rij CM, van der Sangen MJ, Beukema JC, Rütten H, Spruit PH, Reinders JG, Richel DJ, van Berge Henegouwen MI, Hulshof MC. Patterns of recurrence after surgery alone versus preoperative chemoradiotherapy and surgery in the CROSS trials. J Clin Oncol 2014; 32: 385-391.

14. Burmeister BH, Walpole ET, Burmeister EA, Thomas J, Thomson DB, Harvey JA, Mark Smithers B, Gotley DC. Feasibility of chemoradiation therapy with protracted infusion of 5-fluorouracil for esophageal cancer patients not suitable for cisplatin. Int J Clin Oncol 2005; 10: 256-261.

15. Kermani AT, Vakili R, Dadkhah S, Jafarian AH, Bagheri R. HER-2/neu overxpres sion in esophageal squamous cell carcinoma (ESCC) and its correlation with patient's clinicopathological features. Iran J Cancer Prev 2016; 9. DOI: e5007.

16. Bagheri R, Maddah G, Saeidi HS, Sadeghian M, Roodbari S. Bone marrow involvement in esophageal cancer patients whom underwent surgical resection. Eur J Cardiothorac Surg 2011; 40: 343-346. 